\title{
Habitat requirements of Polygonetum natantis Soó 1927 and Potamogetonetum natantis Soó 1927 phytocenoses in north-eastern Poland
}

STANISLAW KLOSOWSKI, HENRYK TOMASZEWICZ

Department of Phytogeography, University of Warsaw, Al. Ujazdowskie 4, 00-478 Warszawa, Poland

(Received: July 25, 1985. Accepted: October 10, 1985)

\begin{abstract}
Comparison of habitats of Polygonetum natantis Soó 1927 and Potamogetonetum natantis Soó 1927 phytocenoses as regards physical and chemical properties of the water and substrate demonstrated that the habitat requirements of both these communities are different. Polygonetum natantis phytocenoses indicate a substrate poor in nutrient components and rich waters, whereas Potamogetonetum natantis patches, on the contrary, are evidence of fertile substrate and waters poor in biophilous components. The differences in habitat conditions demonstrated between the examined communities confirm the correctness of narrow classification of aquatic plant communities, based on floristic dominance.
\end{abstract}

Key words: Polygonetum natantis, Potamogetonetum natantis, habitat requirements, water properties, properties of substrate, differences between habitats

\section{INTRODUCTION}

The rapidly progressing eutrophication of waters has evoked a greater interest in the habitat requirements of aquatic and rush plants as potential indicators of changes occurring in water bodies and water courses. Papers dealing with these problems, however, are mainly focussed on the particular species (Misra 1938, Moyle 1945, Olsen 1950a, b, Kohler 1971, Pietsch 1972, Seddon 1972, Kohler et al. 1974, Melzer 1976, Felzines 1977, Peverly 1979, Wi egleb and Todeskino 1983). Investigations on communities of plants growing in various types of waters comprise above all considerations on the floristic composition of the phytocenoses, their structure, classification 
and chorology (Den Hartog and Segal 1964, Segal 1968, Tomaszewicz 1973, 1977a, b, 1979, Podbielk owski and Tomaszewicz 1974, Oberdorfer 1977, Wiegleb 1983 and others). The habitat conditions of these communities are but little known (with a few exceptions-Pearsall 1920 , Wiegleb 1978, Arendt 1981, Wheeler and Giller 1982). This fact prompted the Department of Phytogeography of the Warsaw University to start wider research on the ecological amplitude and bioindicator value of aquatic and rush vegetation communities in Poland. The first papers taking into account extensively the properties of aquatic and rush habitats (K łosowski and Tomaszewicz 1984, Kłosowski 1985 - in press, Nieckuła and Podyma 1985) demonstrated the existence of distinct connections between water chemism and substrate, and narrowly considered plant communities (based on the principle of floristic dominance). The investigation results at the same time indicated the possibility of utilising some communities as indicators of certain habitats.

The present paper is a continuation of the above mentioned theme and its purpose is to describe the habitat conditions and demonstrate the degree of their diversity in the case of Polygonetum natantis and Potamogetonetum natantis phytocenoses. The latter are classified by some authors (e.g. Hilbig 1971) as the association Polygono-Potametum natantis Soó 1964 which seems to be an artificial syntaxon. The same phytocenoses are also frequently described as facies or variants of the association Myriophyllo-Nupharetum W. Koch 1926 (e.g. Rejewski 1977, Meria ux 1978 and others).

MATERIAL AND METHODS

Material for study was collected in the north-eastern part of Poland in the period 1978-1984 in the area of the Lakelands of Suwałki, Sejny, Ełk as well as the Masurian Lakeland and Augustów forest complex. A total of 29 phytocenoses of Polygonetum natantis and 33 of Potamogetonetum natantis from 41 water bodies were examined. Phytosociological records were made in representative patches of the associations by the Braun-Blanquet method (1951) and water and substrate samples were taken for physicochemical analysis. Substrate samples were taken from the rhizome-root layer by means of a bottom sampler of Mordukhay-Bołtovskoy type, attached to a transparent plexiglass tube for evaluating the depth of the rhizome-root zone. The water samples were taken above the bottom into plastic containers.

In hydrochemical analyses the following parametres were determined: oxygen saturation and $\mathrm{BOD}_{5}$ by Winkler's method, carbon dioxide (free) 
by the titrimetric method with sodium hydroxide, $\mathrm{pH}$ in a digital $\mathrm{pH}$-metre N-517, total nitrogen by Kjeldahl's method, ammonium nitrogen by distillation, oxidability in acid medium, COD by the dichromate method, total and carbonate hardness with the use of the Warthy Pfeifer sodium mixture, chlorides argentometrically after Mohr, soluble silica by the molybdenum method, iron by the colorimetric rhodanate method, magnesium colorimetrically with titanium yellow, nitrate nitrogen colorimetrically with phenoldisulphonic acid, phosphates colorimetrically with ammonium molybdate and stannous chloride, calcium, sodium and potassium by flame photometry on a Flapho 4 photometre, sulphates by weighing, colour according to the platinum-cobalt score.

In substrate samples $\mathrm{pH}$, oxidability, carbon dioxide (free), hydration and organic matter content were directly determined. Sodium and potassium were determined in the calcinated sediment after determination of hydration and organic matter content. For determining other properties the samples were prepared by mineralisation (total nitrogen), aqueous extraction (chlorides, nitrates, soluble silica), acid extraction with HCL $1+1$ (iron, calcium. magnesium, sulphates, phosphates). Most analyses were performed by the methods described for hydrochemical analyses. Hydration was determined by drying substrate samples at $105^{\circ} \mathrm{C}$ to constant weight and organic matter content by combustion of dry samples at $550 \mathrm{C}$ for $1.5 \mathrm{~h}$. Both water and substrate samples were analysed immediately after bringing them to the field laboratory. They were stored as described in the paper of $\mathrm{Her}$ manowicz et al. (1976).

Numerical data were statistically elaborated. For each component and factor in the water and in the substrate mean values and their confidence intervals were calculated. The significance of differences between mean values of the particular features of the habitats of both communities were calculated by means of Student's t test with assumption of a $5 \%$ risk of error. For comparing the Potamogetonetum natantis and Polygonetum natantis habitats as regards all the analysed water properties and all those of the substrate, the characteristics were standardised and the biometric method of ,trait lines” (Jentys-Szaferowa 1951, Matuszkiewicz 1974) was applied.

In view of the character of the present study and the fact that the floristic-phytosociological structure of both the examined communities is known and widely documented (Tomaszewicz 1979), the basic phytosociological data of the compared phytocenoses are presented in concise form in one synthetic table (Table 1).

The distribution of sites or groups of sites of Potamogetonetum natantis and Polygonetum natantis phytocenoses, thus the sampling sites of water and substrate are shown in the map (Fig. 1). 


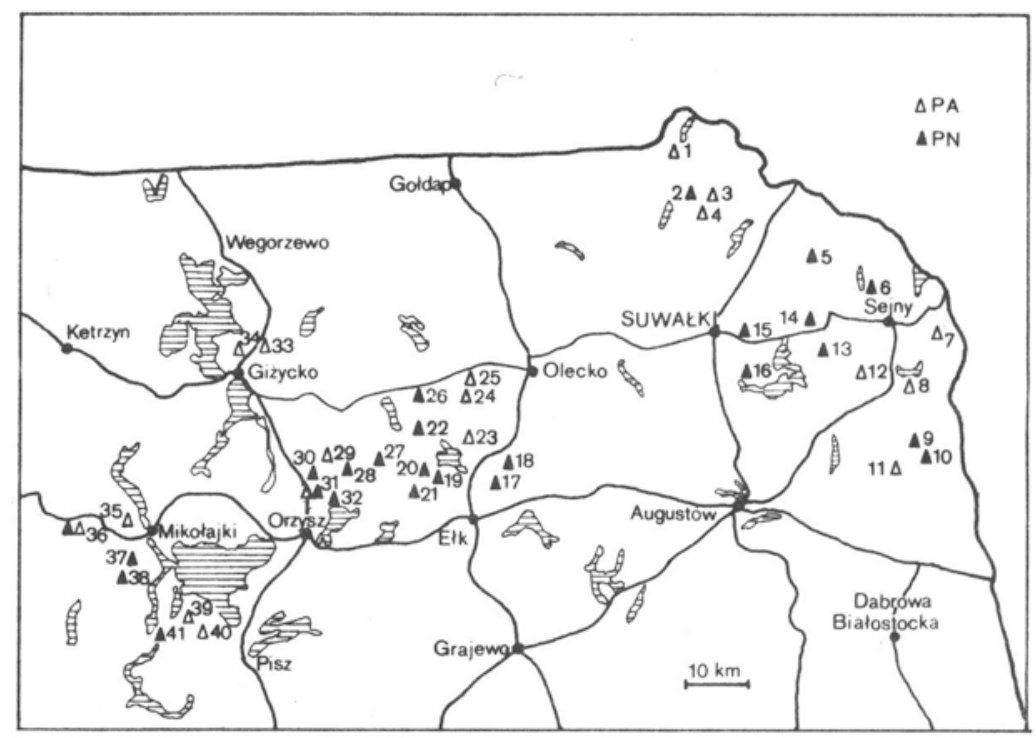

Fig. 1. Sites or groups of sites of the phytocenoses of the studied plant associations (sampling sites). PA - Polygonetum natantis, PN - Potamogetonetum natantis. 1 - lake Wiżajny near Wiżajny, 2 - lake Perty near Smolniki, 3-astatic water body I near Sidory, 4 -astatic water body II near Sidory, 5 - lake Boksze near Smolany, 6 - lake Plaskie near Klejwy, 7 - lake Berżniki near Berżniki, 8 -lake Pomorze near Giby, 9 - lake Brożane near Rygol, 10 - lake Sinkewelen near Rygol, 11 - Augustów canal near Mikaszówka, 12 - lake Pogorzelec near Pogorzelec, 13 - lake Dechłe near Gremzdy Polskie, 14 - lake Żubrowo near Krasne, 15 - lake Czarne near Krzywe, 16 - lake Muliczne near Gawrych-Ruda, 17 - lake Płociczno near Straduny, 18 - lake Krzywionka near Gąski, 19 - lake Żabieniec near Jeziorowskie, 20 - lake Sawinda Mała near Jeziorowskie, 21 - lake Sawinda Duża near Grabnik, 22 - lake Zawadzkie near Zawady, 23 - lake Łaśmiady near Sajzy, 24 pond I in Doliwy, 25 - pond II in Doliwy, 26-lake Wronki near Wronki, 27 - lake Garbas near Liski, 28 - lake Okrągłe near Talki, 29 -astatic water body near Talki, 30 - lake Przykop near Danowo, 31 - lake Łazduny near Danowo, 32 - lake Kieplin near Danowo, 33 - astatic water body I near Giżycko, 34 - astatic water body II near Giżycko, 35 - lake Głębokie near Mikołajki, 36 - lake Kuc near Kosewo, 37 - lake Lisunie near Zełwągi, 38 - lake Gardyńskie near Skok, 39 - lake Jegocin near Wejsuny, 40 - lake Jegocinek II near Wejsuny, 41 - lake Guzianka Wielka near Ruciane-Nida

\section{RESULTS}

PHYTOSOCIOLOGICAL COMPARISON OF POLYGONETUM NATANTIS AND POTAMOGETONETUM NATANTIS PHYTOCENOSES

In north-eastern Poland Polygonetum natantis and Potamogetonetum natantis are represented exclusively by facially developed, compact, usually two- or three-layer floristically poor phytocenoses (Table 1). 
Table 1

Basic, phytosociological data of the communities comnared

Braun-Blanquet method. Constancy: I- $V_{\text {; }}$ Abundances $+, 1,2,3,4,5$; Coeffic of cover: 1-8750

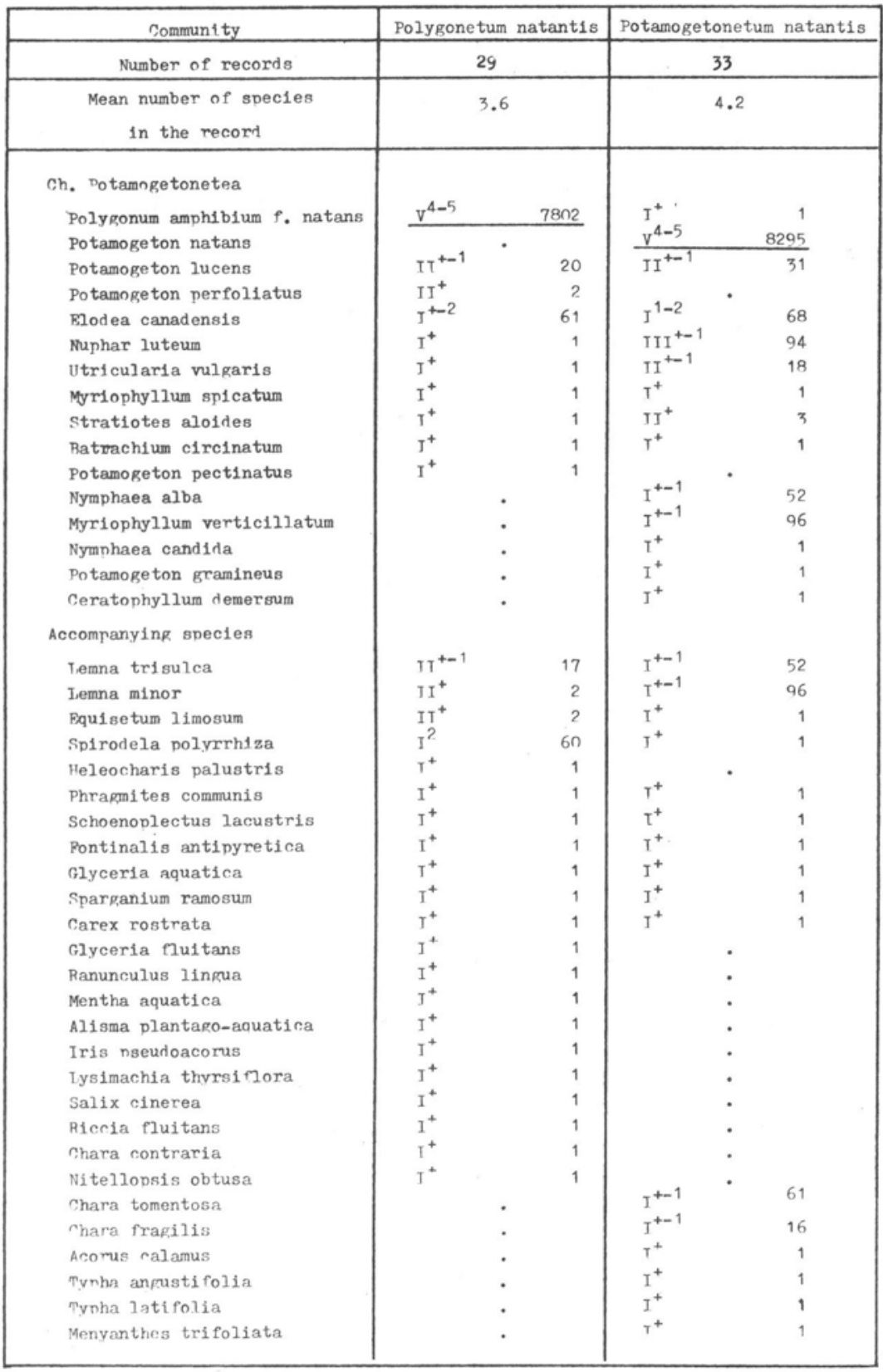


Potamogetonetum natantis patches exhibit a relatively wide participation of species from the alliance Nymphaeion, especially Nuphar luteum, Utricularia vulgaris and Stratiotes aloides which attain here the II and III class of constancy. From among species with immersed leaves (Potamogetonion alliance) most frequent in the phytocenoses is only Potamogeton lucens. In contrast to the Potamogetonetum natantis patches, species from the alliance Nymphaeion are practically absent in Polygonetum natantis phytocenoses, the dominant Polygonum amphibium f. natans excepted, or they occur only sporadically. Species of the alliance Potamogetonion Potamogeton lucens and $P$. perfoliatus are the only ones playing a certain role here. In both the compared communities the participation of accompanying species is small. A greater constancy of Lemna minor and L. trisulca is only noted in Potamogetonetum natantis, and in Polygonetum natantis, of Equisetum limosum (class II of constancy).

Potamogetonetum natantis phytocenoses develop usually within water bodies in the zone of plant communities with floating leaves, bordering on the land side on phytocenoses of rush associations (Phragmitetum, Typhetum angustifoliae, Thelypteridi-Phragmitetum and sometimes Cladietum marisci) or aquatic ones (Nupharo-nymphaetum albae, Hydrocharitetum morsus-ranae). On the deep-water side they frequently neighbour Charetum tomentosae or Elodeetum canadensis or else Myriophylletum verticillati phytocenoses. In numerous cases they occupy extensive areas in the shallowing bays of lakes and do not contact directly any other communities. Polygonetum natantis patches, otherwise than those of Potamogetonetum natantis, form frequently small enclaves among high rush communities (Phragmition alliance) in shallow parts of the water bodies. When they are present in the zone of communities of the Nymphaeion alliance they usually develop in the form of a narrow belt bordering on the land side directly on cattail (Typha) communities or reed. These littoral segments are often exposed to waves, hence on the deep-water side there are no other communities of aquatic plants. Polygonetum natantis phytocenoses have not been noted in shallow parts of lake bays as is the case for Potamogetonetum natantis patches. Patches of Polygonetum natantis are, however, found quite frequently occupying central parts of whole surfaces of astatic water bodies or ponds.

COMPARISON OF HABITATS OF THE STUDIED PHYTOCENOSES

General properties of the habitats

The phytocenoses of both the associations appear on the study area in various types of water bodies. However, as far as Potamogetonetum natantis patches are mainly associated with lakes, the Polygonetum natantis 
phytocenoses appear as frequently in lakes as in astatic water bodies and also sometimes in ponds.

There are noticeable habitat differences between the studied communities in the substrate character. Potamogetonetum natantis phytocenoses occupy mainly mineral-organic substrates with a high degree of comminution or organic-mineral ones, usually with a large proportion of calcium gyttja. Polygonetum natantis patches, on the other hand, are associated with sandy substrates, quite often sandy-gritty ones (especially on bare littoral segments). In astatis water bodies the substrates in Polygonetum natantis phytocenoses are usually clayey and organic substrates are extremely rare.

Wide differences between the studied associations are also noted as regards water depth in the phytocenoses. Potamogetonetum natantis phytocenoses reach mostly down to a depth of about $1.5 \mathrm{~m}$, frequently even $2.0-2.5 \mathrm{~m}$, whereas Polygonetum natantis patches develop most frequently either at a depth not exceeding $1 \mathrm{~m}$ (chiefly in astatic water bodies) or at depths slightly exceeding $1 \mathrm{~m}$, phytocenoses reaching down to about $2.0 \mathrm{~m}$ are extremely rare.

The communities are also characterised by a different sensitivity to water undulation. On the investigated area Potamogetonetum natantis phytocenoses show a high sensitivity to this factor, therefore, they reach optimal development within calm bays where they often occupy wide areas (e.g. lakes: Dechłe, Brożane, Czarne, Żabieniec). Polygonetum natantis patches. on the contrary, are not at all sensitive to any water movements, either undulation or changes in water level which are frequent especially in astatic water bodies.

Physicochemical properties of aquatic habitats

Twenty one components and parametres of aquatic habitats of Polygonetum natantis and Potamogetonetum natantis have been characterised. Numerical data (mean values and ranges of variability of the particular properties are presented in Table 2, and the results are shown synthetically in the graph of "trait lines" (Fig. 2) which allows to simultaneously compare the habitats of the studied associations as regards all the analysed physicochemical properties of the waters. In this graph standardized values of the particular features of the compared habitats are shown for each community in the form of points joined by a broken line. A vertical line runs from points zero of the scale, separating ranges below and above the means for both habitats.

It is clearly seen from the data in the graph and table that there are wide differences between the aqueous habitats of the studied communities. 


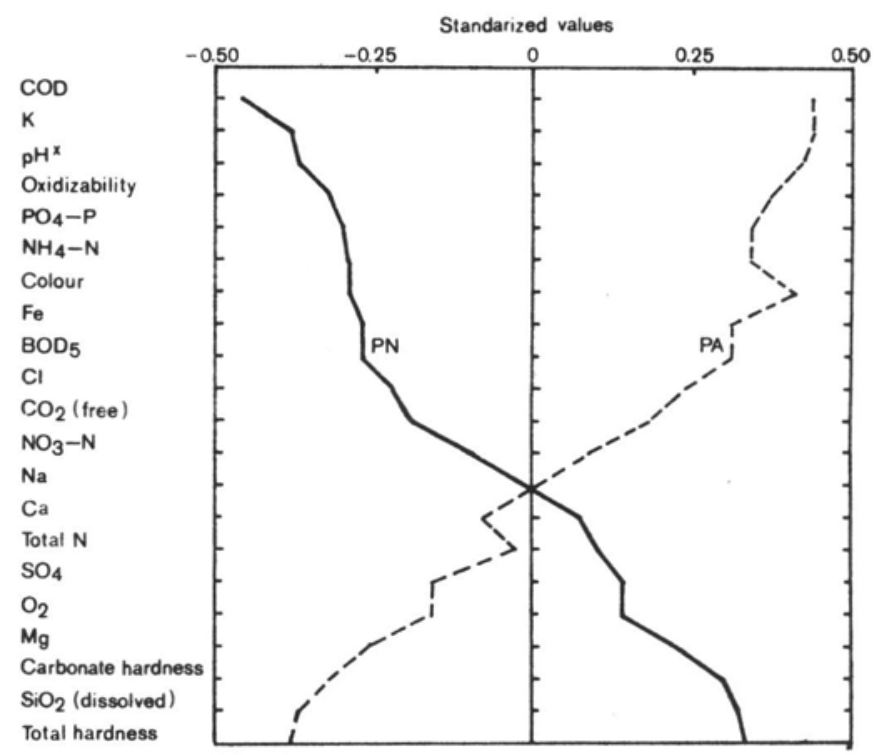

Fig. 2. "Trait lines" of physicochemical properties of aquatic habitats of Potamogetonetum natantis (PN) and Polygonetum natantis (PA) habitats. $\mathrm{pH}$ after conversion to specific acidity (Wherry 1922)

The widest (statistically significant) ones concern as many as 12 characteristics: $\mathrm{COD}$, oxidability, $\mathrm{BOD}_{5}$. colour, $\mathrm{pH}$, total and carbonate hardness, $\mathrm{K}$. $\mathrm{PO}_{4}-\mathrm{P}, \mathrm{NH}_{4}-\mathrm{N} . \mathrm{Fe}$ and $\mathrm{SiO}_{2}$. contents. Among these twelve characteristics noteworthy are above all those indicating directly the purity and fertility of the water: phosphates constituting one of the main components which limit life in waters, ammonium nitrogen. potassium, iron, colour and $\mathrm{BOD}_{5}$. COD and oxidability. The latter three factors point to the content of various forms of organic matter in the water $\left(\mathrm{BOD}_{5}\right.$ mainly of relatively readily decomposable compounds and oxidability. and COD of difficultly decomposable ones). The mean values of the above enumerated components and factors are significantly lower in waters with Potamogetonetum natantis phytocenoses. The $\mathrm{Cl}, \mathrm{CO}_{2}$ and $\mathrm{NO}_{3}-\mathrm{N}$ values are also lower here. although the differences have not been found to be statistically significant between the compared habitats. It may be stated in general that these waters are pure, in contrast to the water in which Polygonetum natantis phytocenoses grow and which are much poorer in biophilous substances. Among other characteristics worth mentioning is the significant difference between the compared habitats in $\mathrm{pH}$. The more alkaline waters (lower specific acidity values - Table 2. Fig. 2) are associated with Potamogetonetum natantis phytocenoses, whereas Polygonetum natantis patches appear usually in more acidic waters - this is particularly true of astatic water 
Table 2

Properties of water in habitats of Polygonetum natantis /1/ and Potamogetonetum natantis /2/

\begin{tabular}{|c|c|c|c|c|c|c|c|}
\hline \multicolumn{2}{|l|}{ Property } & \multicolumn{2}{|c|}{ Mean $\pm 95 \%$ c. 1.} & \multicolumn{2}{|c|}{ Range } & \multirow{2}{*}{$\begin{array}{c}n \\
29 \\
28\end{array}$} & \multirow{2}{*}{$\frac{\text { Signiflcance }}{+}$} \\
\hline $\begin{array}{l}\mathrm{COD} \\
\mathrm{mg} \mathrm{O}\end{array}$ & $\begin{array}{l}1 \\
2\end{array}$ & $\begin{array}{l}47.06 \\
22.23 \\
\end{array}$ & $\begin{array}{r} \pm 13.06 \\
\pm \quad 2.81 \\
\end{array}$ & $\begin{array}{r}12.40 \\
8.20\end{array}$ & $\begin{array}{r}-134.40 \\
-\quad 38.00 \\
\end{array}$ & & \\
\hline $\mathrm{mg} \cdot d \mathrm{~m}^{-3}$ & $\begin{array}{l}1 \\
2\end{array}$ & $\begin{array}{l}2.87 \\
1.11\end{array}$ & $\begin{array}{l} \pm 1.06 \\
\pm \quad 0.24 \\
\end{array}$ & $\begin{array}{l}0.30 \\
0.25\end{array}$ & $\begin{array}{l}-\quad 12.50 \\
-\quad 2.58 \\
\end{array}$ & $\begin{array}{l}29 \\
33\end{array}$ & + \\
\hline $\mathrm{pH}$ & $\begin{array}{l}1 \\
2\end{array}$ & $\begin{array}{l}7.3 \\
7.9 \\
\end{array}$ & & $\begin{array}{l}6.6 \\
7.3 \\
\end{array}$ & $\begin{array}{l}-8.8 \\
-\quad 8.9 \\
\end{array}$ & $\begin{array}{l}29 \\
33 \\
\end{array}$ & + \\
\hline $\begin{array}{l}\text { Oxid1zability } \\
\mathrm{mg} \mathrm{O} \mathrm{O}_{2} \cdot \mathrm{dm}^{-3}\end{array}$ & $\begin{array}{l}1 \\
2 \\
\end{array}$ & $\begin{array}{r}13.24 \\
8.03 \\
\end{array}$ & $\begin{array}{l} \pm \quad 3.89 \\
\pm \quad 0.79 \\
\end{array}$ & $\begin{array}{l}3.50 \\
3.50\end{array}$ & $\begin{array}{l}-45.00 \\
-\quad 13.00 \\
\end{array}$ & $\begin{array}{l}29 \\
33\end{array}$ & + \\
\hline $\begin{array}{l}\mathrm{PO}_{4}-\mathrm{P} \\
\mathrm{mg} \cdot \mathrm{dm}^{-3}\end{array}$ & $\begin{array}{l}1 \\
2\end{array}$ & $\begin{array}{l}0.276 \\
0.041 \\
\end{array}$ & $\begin{array}{l} \pm \quad 0.190 \\
\pm \quad 0.022 \\
\end{array}$ & $\begin{array}{l}0.000 \\
0.000 \\
\end{array}$ & $\begin{array}{l}1.600 \\
0.230 \\
\end{array}$ & $\begin{array}{l}29 \\
33 \\
\end{array}$ & + \\
\hline $\begin{array}{l}\mathrm{NH}_{4}-\mathrm{N} \\
\mathrm{mg} \cdot \mathrm{dm}^{-3}\end{array}$ & $\begin{array}{l}1 \\
2\end{array}$ & $\begin{array}{l}1.47 \\
0.31 \\
\end{array}$ & $\begin{array}{l} \pm 0.98 \\
\pm \quad 0.07 \\
\end{array}$ & $\begin{array}{l}0.00 \\
0.00 \\
\end{array}$ & $\begin{array}{r}8.60 \\
-\quad 0.75 \\
\end{array}$ & $\begin{array}{l}29 \\
33 \\
\end{array}$ & + \\
\hline $\begin{array}{l}\text { Colour } \\
\mathrm{mg} \mathrm{Pt} \cdot \mathrm{dm}^{-3}\end{array}$ & $\begin{array}{l}1 \\
2\end{array}$ & $\begin{array}{l}65 \\
24 \\
\end{array}$ & $\begin{array}{r} \pm \quad 30 \\
\pm \quad 4 \\
\end{array}$ & $\begin{array}{l}5 \\
6 \\
\end{array}$ & $\begin{array}{l}-280 \\
-\quad 42 \\
\end{array}$ & $\begin{array}{l}29 \\
33\end{array}$ & + \\
\hline $\begin{array}{l}\text { Pe } \\
\mathrm{mg} \cdot \mathrm{dm}^{-3}\end{array}$ & $\begin{array}{l}1 \\
2 \\
\end{array}$ & $\begin{array}{l}0.757 \\
0.098 \\
\end{array}$ & $\begin{array}{l} \pm 0.606 \\
\pm \quad 0.037 \\
\end{array}$ & $\begin{array}{l}0.000 \\
0.000 \\
\end{array}$ & $\begin{array}{l}5.900 \\
-\quad 0.320 \\
\end{array}$ & $\begin{array}{l}29 \\
33 \\
\end{array}$ & + \\
\hline $\begin{array}{l}\mathrm{BOD}_{5} \\
\mathrm{mg} \mathrm{O}_{2} \cdot \mathrm{dm}^{-3}\end{array}$ & $\begin{array}{l}1 \\
2\end{array}$ & $\begin{array}{l}3.21 \\
2.19\end{array}$ & $\begin{array}{ll} \pm & 0.88 \\
\pm \quad 0.28 \\
\end{array}$ & $\begin{array}{l}0.90 \\
0.60\end{array}$ & $\begin{array}{r}-\quad 10.00 \\
-\quad 3.60 \\
\end{array}$ & $\begin{array}{l}29 \\
33\end{array}$ & + \\
\hline 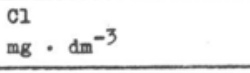 & $\begin{array}{l}1 \\
2 \\
\end{array}$ & $\begin{array}{l}14.13 \\
10.93 \\
\end{array}$ & $\begin{array}{l} \pm \quad 3.56 \\
\pm \quad 1.20 \\
\end{array}$ & $\begin{array}{l}3.90 \\
5.30 \\
\end{array}$ & $\begin{array}{l}-\quad 44.67 \\
-\quad 17.65 \\
\end{array}$ & $\begin{array}{l}29 \\
33 \\
\end{array}$ & - \\
\hline $\begin{array}{l}\mathrm{CO}_{2} \text { free } \\
\mathrm{mg} \cdot \mathrm{dm}^{-3}\end{array}$ & $\begin{array}{l}1 \\
2 \\
\end{array}$ & $\begin{array}{l}6.19 \\
3.74 \\
\end{array}$ & $\begin{array}{l} \pm \quad 3.23 \\
\pm \quad 1.35 \\
\end{array}$ & $\begin{array}{l}0.00 \\
0.00 \\
\end{array}$ & $\begin{array}{l}-24.20 \\
-\quad 13.20 \\
\end{array}$ & $\begin{array}{l}29 \\
28\end{array}$ & - \\
\hline $\begin{array}{l}\mathrm{NO}_{3}-\mathrm{N} \\
\mathrm{mg} \cdot \mathrm{dm}^{-3}\end{array}$ & $\begin{array}{l}1 \\
2 \\
\end{array}$ & $\begin{array}{l}0.066 \\
0.058 \\
\end{array}$ & $\begin{array}{ll} \pm & 0.018 \\
\pm \quad 0.014 \\
\end{array}$ & $\begin{array}{l}0.000 \\
0.000 \\
\end{array}$ & $\begin{array}{l}-\quad 0.180 \\
-\quad 0.140 \\
\end{array}$ & $\begin{array}{l}29 \\
33 \\
\end{array}$ & - \\
\hline $\mathrm{ma} \cdot \mathrm{dm}^{-3}$ & $\begin{array}{l}1 \\
2 \\
\end{array}$ & $\begin{array}{l}3.72 \\
3.74 \\
\end{array}$ & $\begin{array}{l} \pm \quad 0.78 \\
\pm \quad 0.63 \\
\end{array}$ & $\begin{array}{l}0.80 \\
0.50 \\
\end{array}$ & $\begin{array}{r}10.30 \\
-\quad 9.10 \\
\end{array}$ & $\begin{array}{l}29 \\
33 \\
\end{array}$ & - \\
\hline $\begin{array}{l}\mathrm{mg} \\
\mathrm{mg} \cdot \mathrm{dm}^{-3}\end{array}$ & $\begin{array}{l}1 \\
2 \\
\end{array}$ & $\begin{array}{l}42.93 \\
45.17 \\
\end{array}$ & $\begin{array}{r} \pm \quad 6.61 \\
\pm \quad 4.26 \\
\end{array}$ & $\begin{array}{l}10.71 \\
17.16 \\
\end{array}$ & $\begin{array}{r}87.96 \\
-\quad 64.97 \\
\end{array}$ & $\begin{array}{l}29 \\
33\end{array}$ & - \\
\hline $\begin{array}{l}\text { Total }-\mathrm{N} \\
\mathrm{mg} \cdot \mathrm{dm}^{-3}\end{array}$ & $\begin{array}{l}1 \\
2\end{array}$ & $\begin{array}{l}6.93 \\
7.39 \\
\end{array}$ & $\begin{array}{r} \pm 1.29 \\
\pm \quad 1.34 \\
\end{array}$ & $\begin{array}{l}2.80 \\
1.40 \\
\end{array}$ & $\begin{array}{l}14.70 \\
-\quad 14.00 \\
\end{array}$ & $\begin{array}{l}29 \\
28\end{array}$ & - \\
\hline $\mathrm{mg}_{4}^{\mathrm{SO}_{4}} \cdot \mathrm{dm}^{-3}$ & $\begin{array}{l}1 \\
2\end{array}$ & $\begin{array}{l}23.20 \\
26.41 \\
\end{array}$ & $\begin{array}{l} \pm \quad 4.59 \\
\pm \quad 3.52 \\
\end{array}$ & $\begin{array}{l}4.92 \\
8.00 \\
\end{array}$ & $\begin{array}{l}-\quad 45.96 \\
-\quad 52.25 \\
\end{array}$ & $\begin{array}{l}29 \\
33 \\
\end{array}$ & - \\
\hline $\mathrm{O}_{2}$ & $\begin{array}{l}1 \\
2 \\
\end{array}$ & $\begin{array}{l}85.5 \\
94.1 \\
\end{array}$ & $\begin{array}{r} \pm 13.9 \\
\pm \quad 7.6 \\
\end{array}$ & $\begin{array}{r}6.0 \\
49.2\end{array}$ & $\begin{array}{l}-124.2 \\
-\quad 157.0\end{array}$ & $\begin{array}{l}29 \\
33 \\
\end{array}$ & - \\
\hline $\begin{array}{l}\mathrm{Mg} \\
\mathrm{mg} \cdot \mathrm{dm}^{-3} \\
\end{array}$ & $\begin{array}{l}1 \\
2 \\
\end{array}$ & $\begin{array}{l}10.27 \\
13.66 \\
\end{array}$ & $\begin{array}{l} \pm \quad 2.15 \\
\pm \quad 2.69 \\
\end{array}$ & $\begin{array}{l}1.71 \\
4.70 \\
\end{array}$ & $\begin{array}{r}-24.39 \\
-\quad 34.15 \\
\end{array}$ & $\begin{array}{l}29 \\
33 \\
\end{array}$ & - \\
\hline $\begin{array}{l}\text { Carbonate hardness } \\
\text { mval } \cdot \mathrm{dm}^{-3}\end{array}$ & $\begin{array}{l}1 \\
2\end{array}$ & $\begin{array}{l}2.47 \\
2.98 \\
\end{array}$ & $\begin{array}{l} \pm \quad 0.38 \\
\pm \quad 0.18 \\
\end{array}$ & $\begin{array}{l}0.45 \\
1.90 \\
\end{array}$ & $\begin{array}{l}4.50 \\
4.20 \\
\end{array}$ & $\begin{array}{l}29 \\
33 \\
\end{array}$ & + \\
\hline $\begin{array}{l}\mathrm{S1O}_{2} \mathrm{~d} 1 \mathrm{ssolved} \\
\mathrm{mg} \cdot \mathrm{dm}^{-3}\end{array}$ & $\begin{array}{l}1 \\
2 \\
\end{array}$ & $\begin{array}{l}2.37 \\
5.07 \\
\end{array}$ & $\begin{array}{l}0.88 \\
1.61 \\
\end{array}$ & $\begin{array}{l}0.00 \\
0.50\end{array}$ & $\begin{array}{r}-\quad 9.00 \\
-\quad 17.10 \\
\end{array}$ & $\begin{array}{l}29 \\
33 \\
\end{array}$ & + \\
\hline $\begin{array}{l}\text { Total hardness } \\
\text { mval } \cdot \mathrm{dm}^{-3}\end{array}$ & $\begin{array}{l}1 \\
2\end{array}$ & $\begin{array}{l}3.04 \\
3.75\end{array}$ & $\begin{array}{l} \pm 0.43 \\
\pm \quad 0.28 \\
\end{array}$ & $\begin{array}{l}0.73 \\
2.26\end{array}$ & $\begin{array}{l}5.35 \\
5.90 \\
\end{array}$ & $\begin{array}{l}29 \\
33 \\
\end{array}$ & + \\
\hline
\end{tabular}

$\mathrm{pH}$ - statistically treated after conversion 1nto spec1fic acidity, according to Wherry /1922/, + - significant differences, - - Insignificant differences. c.1. - confidence interval. 
bodies with stagnant water, where the proportion of organic matter, especially of humic substances acidifying the water may be higher. Apart from the significantly higher $\mathrm{pH}$ value, the waters in which Potamogetonetum natantis develops have also a significantly higher soluble silica content and hardness, both total and carbonate. This is probably connected with a higher calcium and especially magnesium content in the water. It may be affirmed on the basis of mean total hardness values that Potamogetonetum natantis phytocenoses occupy generally water of medium hardness, and Polygonetum natantis patches prefer soft waters or those of intermediate character.

The significant mean differences in many characteristics are accompanied also by significant differences in their amplitudes in the compared habitats (Table 2). In this respect Potamogetonetum natantis phytocenoses exhibit markedly more definite requirements concerning the water properties. As compared with water habitats of Potamogetonetum natantis, Polygonetum natantis occupies waters with much narrower $\mathrm{COD}$, potassium, $\mathrm{pH}$, oxidability, ammonium nitrogen, phosphates, colour, iron, $\mathrm{BOD}_{5}$, chlorides, carbon dioxide, total and carbonate hardness amplitudes. Among all the analysed components and factors only soluble silica content showed a wider amplitude in the aquatic habitat with Potamogetonetum natantis phytocenoses. The amplitudes of the remaining characteristics in both habitats are similar.

In general, the obtained data indicate that Potamogetonetum natantis has a distinctly narrower ecological amplitude as far as the water habitat is concerned. Phytocenoses of this association on the study area are mainly associated with waters of mesotrophic type.

\section{Physicochemical properties of the substrates}

The substrates on which Polygonetum natantis and Potamogetonetum natantis develop have been characterised on the basis of the same 14 components and factors as those concerning waters, moreover, the organic matter content and hydration were taken into account. The numerical results, similarly as in the case of waters, are presented synthetically in a graph and listed in a table (Fig. 3 and Table 3).

Analysis of the results leads to the conclusion that the differences between the substrates of the phytocenoses of both the plant associations are more univocal as compared with aquatic habitat differences. It is seen distinctly (particularly in the graph of "trait lines") that for Polygonetum natantis mean values of practically all the substrate characteristics $(\mathrm{pH}$ excepted, this resulting from the character of this index and the necessity of converting $\mathrm{pH}$ values of specific acidity) are lower than those determined in the substrates of Potamogetonetum natantis phytocenoses. Thus, the former 
Table 3

Properties of substrate in habitats of Polygonetum natant1s /1/ and Potamogetonetum natantis /2/

\begin{tabular}{|c|c|c|c|c|c|c|c|}
\hline \multicolumn{2}{|l|}{ Property } & \multicolumn{2}{|c|}{ Mean $\pm 95 \%$ c.1. } & \multicolumn{2}{|c|}{ Range } & \multirow{3}{*}{$\begin{array}{l}\text { n } \\
29 \\
33\end{array}$} & \multirow{3}{*}{$\frac{\text { S1gniflcance }}{+}$} \\
\hline Fydratation & 1 & 40.7 & 9.7 & 19.1 & 88.4 & & \\
\hline \% & 2 & 78.2 & 4.9 & 46.5 & 95.2 & & \\
\hline $\mathrm{Ca}$ & 1 & 15.60 & \pm 9.03 & 0.30 & -117.80 & 29 & \multirow[b]{2}{*}{+} \\
\hline$g \cdot \mathrm{kg}^{-1} \mathrm{~d}_{0} w t$. & 2 & 155.56 & $\pm \quad 35.04$ & 2.40 & $-\quad 380.5$ & 33 & \\
\hline & 1 & 0.23 & 0.10 & 0.00 & 0.85 & 29 & \multirow[b]{2}{*}{+} \\
\hline$g \cdot \mathrm{kg}^{-1}$ d.wt. & 2 & 0.95 & 0.26 & 0.00 & 3.59 & 33 & \\
\hline $\mathrm{SO}_{4}$ & 1 & 1.35 & $\pm \quad 0.67$ & 1.00 & 9.80 & 29 & \multirow[b]{2}{*}{+} \\
\hline $\mathrm{g} \cdot \mathrm{kg}^{-1}$ d.wt. & 2 & 5.67 & 2.22 & 0.27 & 30.33 & 33 & \\
\hline & 1 & 2.50 & 1.16 & 0.00 & 10.70 & 29 & \multirow[b]{2}{*}{+} \\
\hline$g \cdot \mathrm{kg}^{-1}$ d.wt. & 2 & 11.40 & $\pm \quad 5.50$ & 0.00 & 69.90 & 33 & \\
\hline $\mathrm{S}_{2} \mathrm{O}_{2}$ d1ssolved & 1 & 0.11 & 0.06 & 0.00 & 0.90 & 29 & \multirow[b]{2}{*}{+} \\
\hline$g \cdot \mathrm{kg}^{-1} \mathrm{~d} \cdot \mathrm{wt}$. & 2 & 0.39 & $\pm \quad 0.17$ & 0.01 & 2.79 & 33 & \\
\hline Organ1c matter & 1 & 13.5 & 8.8 & 0.1 & -84.8 & 29 & \multirow[b]{2}{*}{+} \\
\hline \% d.wt. & 2 & 26.8 & 6.2 & 6.2 & 64.1 & 33 & \\
\hline $\mathrm{NO}_{3}-\mathrm{N}$ & 1 & 0.003 & 0.002 & 0.000 & 0.019 & 29 & \multirow{2}{*}{ - } \\
\hline $\mathrm{g} \cdot \mathrm{kg}^{-1}$ d.wt. & 2 & 0.013 & 0.010 & 0.000 & 0.120 & 33 & \\
\hline & 1 & 2.82 & 1.41 & 0.02 & 15.94 & 29 & \multirow{2}{*}{ - } \\
\hline $\mathrm{g} \cdot \mathrm{kg}^{-1} \mathrm{~d} \cdot \mathrm{wt}$. & 2 & 6.36 & 3.81 & 0.34 & 51.09 & 33 & \\
\hline Total-N & 1 & 3.80 & 3.13 & 0.05 & 31.93 & 29 & \multirow{2}{*}{ - } \\
\hline$g \cdot \mathrm{kg}^{-1}$ d.wt. & 2 & 7.04 & $\pm \quad 2.67$ & 0.29 & $-\quad 30.11$ & 28 & \\
\hline $\mathrm{CO}_{2}$ free & 1 & 1.02 & 0.55 & 0.00 & 6.03 & 29 & \multirow[t]{2}{*}{-} \\
\hline $\mathrm{g} \cdot \mathrm{kg}^{-1} \mathrm{~d}, \mathrm{wt}$. & 2 & 1.51 & 0.56 & 0.00 & 4.85 & 28 & \\
\hline 0x1d1zability & 1 & 42.1 & \pm 27.7 & 0.4 & -265.2 & 29 & \multirow{2}{*}{-} \\
\hline$g \cdot \mathrm{kg}^{-1}$ d.wt. & 2 & 56.7 & $\pm \quad 18.9$ & 5.7 & -230.2 & 33 & \\
\hline $\mathrm{Cl}$ & 1 & 0.53 & \pm 0.31 & 0.02 & 3.24 & 29 & \multirow{2}{*}{ - } \\
\hline$g \cdot \mathrm{kg}^{-1} \mathrm{~d} \cdot \mathrm{wt}$. & 2 & 0.65 & \pm 0.28 & 0.00 & 3.41 & 33 & \\
\hline $\mathrm{PO}_{4}-\mathrm{P}$ & 1 & 0.536 & \pm 0.288 & 0.010 & 3.165 & 29 & \multirow{2}{*}{ - } \\
\hline $\mathrm{g}^{4} \cdot \mathrm{kg}^{-1} \mathrm{~d} \cdot \mathrm{wt}$ & 2 & 0.566 & \pm 0.428 & 0.000 & 6.956 & 33 & \\
\hline $\mathrm{K}$ & 1 & 0.38 & \pm 0.20 & 0.03 & 2.53 & 29 & \multirow{2}{*}{-} \\
\hline$g \cdot \mathrm{kg}^{-1} \mathrm{~d} \cdot \mathrm{wt}$. & 2 & 0.39 & \pm 0.10 & 0.07 & 1.50 & 33 & \\
\hline \multirow{2}{*}{$\mathrm{pH}$} & 1 & 6.5 & & 5.5 & 8.3 & 29 & \multirow{2}{*}{-} \\
\hline & 2 & 7.0 & & 6.2 & 8.6 & 33 & \\
\hline
\end{tabular}

pH - stat1st1cally treated after conversion into specif1c ac1dity, according to Wherry /1922/, + - significant differences, - - insignificant differences, c.1. - confidence interval.

are distinctly mineral poor in nutrients. The substrates on which Potamogetonetum natantis phytocenoses develop are in general richer in biophilous substances and may be considered as relatively fertile. They are characterised by a particularly high calcium content, therefore, frequently with alkaline $\mathrm{pH}$, high sodium, magnesium, soluble silica contents associated with a high degree of hydration and a considerable content of organic matter. The differences in the above mentioned characteristics are the widest (with the exception of $\mathrm{pH}$ ), thus statistically significant. These results indicate that Potamogetonetum natantis 


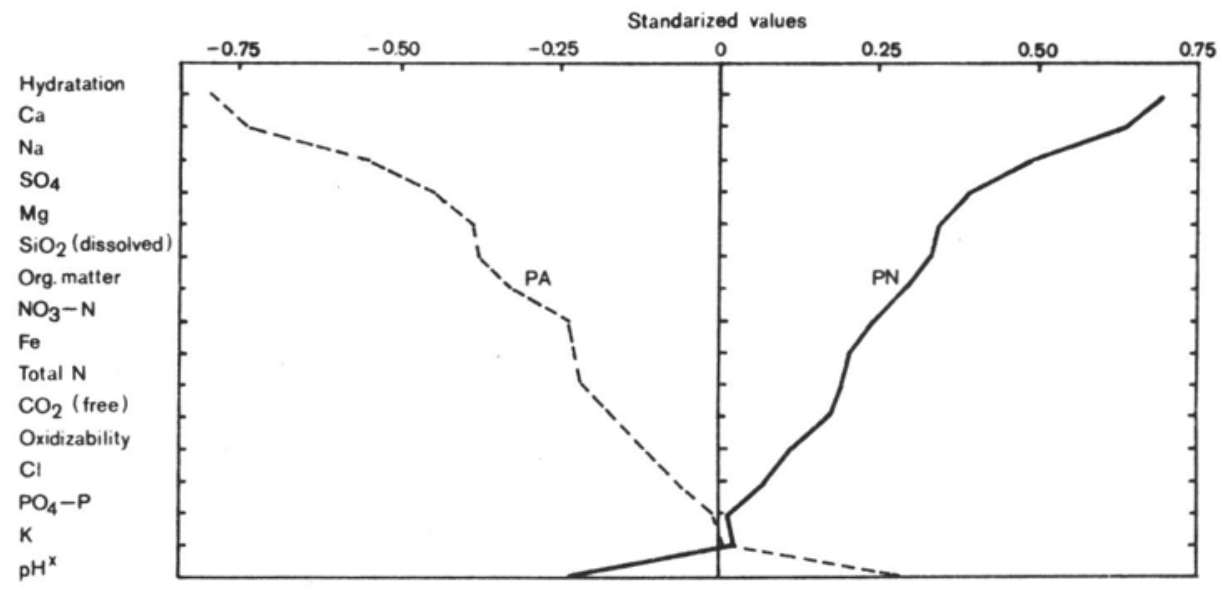

Fig. 3. "Trait lines" of physicochemical properties of substrates of the studied plant communities. Notations as in Fig. 2

phytocenoses are strongly bound with sediments of gyttja calcium, and on such substrates they attain optimum development. Polygonetum natantis patches occupy mainly poorly hydrated mineral substrates particularly poor in calcium, with mostly a slightly acidic or close to neutral $\mathrm{pH}$.

Interesting results were also obtained in the comparison of the amplitudes of the particular analysed characteristics in the substrates of both communities (Table 3). In this respect. contrary as in the aquatic habitat. most components and factors show wide amplitudes (calcium. magnesium. sulphate, nitrates. soluble silica, phosphates, iron) in the substrate of Potamogetonetum natantis. Only the amplitudes of hydration, organic matter content and $\mathrm{pH}$ proved narrower in the substrates of Potamogetonetum natantis phytocenoses. This fact points to the strong bond between the latter phytocenoses and substrate covered with a thick layer of semiliquid organic-mineral sediments.

\section{DISCUSSION}

The results obtained in the present study indicate the existence of very pronounced habitat differences between the phytocenoses of Polygonetum natantis and Potamogetonetum natantis. Some differences have already been reported earlier by authors of phytosociological papers, they concerned however, mainly physical factors such as the character of the substrate. the slope of the lake basin. water depth. and influence of water undulation (Dąmbska 1961. Tomaszewicz 1969. Hilbig 1971. Popiołek 1973. Rejewski 1981. Tomaszewicz and Kłosowski 1985 and others). The here 
mentioned authors, independently of a very different syntaxonomic approach to the Potamogetonetum natantis and Polygonetum natantis phytocenoses usually stressed the occurrence of Potamogeton natans patches in protected calm waters on a substrate with a thick sediment (frequently organic). For Polygonetum natantis, the association of the patches of the aquatic form of Polygonum amphibium dominance with a mineral substrate was chiefly stressed, or less frequently with silty and less protected sites more exposed to waves. Rejewski (1981) called attention to the latter factor, particularly, stressing the greater resistance of Polygonum amphibium $\mathrm{f}$. natans than of Potamogeton natans to the action of waves, both as regards tearing of the plants from the substrate and damage to the shoots caused by gravel driven by the waves. This observation agrees with those of the present authors as regards phytocenoses growing in lakes.

On the basis of these general data, marked differences could be expected between the studied communities, at least as regards the chemism of the substrate, and this has been fully confirmed by the present results. Rather unexpected are, however, the distinct differences concerning the chemism of the water habitats. It is true that up till now no hydrochemical investigations in detail had been performed in the phytocenoses formed by Potamogeton natans of Polygonum amphibium $\mathrm{f}$. natans, however, data from autecological investigations pointed to a similarity of the water habitats, suggesting rather links between both Potamogeton natans and Polygonum amphibium f. natans with oligotrphic (e.g. Felzines 1977), or mesotrophic-eutrophic waters (Wiegleb 1978). Certain data on the aquatic habitats of both plant communities are given by Meriaux (1978) who calls attention to their relatively wide ecological scale. Beside the study of Kłosowski (1985), giving rather detailed data on Potamogetonetum natantis habitats, noteworthy is the paper of Rejewski (1981) calling attention to the role of trophism as one of the prominent factors deciding of the possibility of settling on the littoral of water bodies of hydrophytes and their communities. This author classified both Potamogetonetum natantis and Polygonetum natantis as the result of his investigations in lakes in the environs of Laska in the Bory Tucholskie forest complex, to associations bound with waters of relatively low trophism (oligotrophic). He referred, however, only to his area of study. His data concerning Potamogetonetum natantis are at least partly in agreement with the results of the present study, but not for Polygonetum natantis since this community exhibits in north-eastern Poland an exceptionally wide ecological amplitude of its aquatic habitat. This is manifested in the occupation by phytocenoses with Polygonum amphibium f. natans of water body types differing widely in their hydrochemical character.

The noted habitat differences between the discussed plant communities in north-eastern Poland are, therefore, wider than noted so far by various 
authors. It may be stated that both Potamogetonetum natantis and Polygonetum natantis are on the study area associations which can be unequivocally characterised from the point of view of phytosociology and ecology. Therefore, their classification in one association Polygono-Potametum natantis as done by Hilbig (1971) or their inclusion into Myriophyllo-Nupharetum (Meriaux 1978) or Hydrocharitetum morsus-ranae (Popiołek 1973) is out of question.

The results of the present investigation are once more a confirmation of the correctness of narrow classifying aquatic plant communities on the basis of floristic dominance. At the same time they indicate distinctly strong diverse relations between the phytocenoses and the habitat. dependent on the type of community. It appeared for instance that the substrate and water, irrespective of their relations, have a distinctly diverse signifincance for various communities. as has been earlier mentioned (K łosowski 1985). This fact has been plainly confirmed in the case of the here described two communities. The differences demonstrated between both as regards water properties and substrate, suggest, moreover, that these communities may be of definite indicator value. This value may be considered in practice independently, in relation to the two basic components of the habitat such as substrate and water. In the case of Potamogetonetum natantis we may speak of the indicator value of this phytocenosis for the aquatic habitat (mesotrophic waters), and of Polygonetum natantis for the substrate (mineral substrate poor in nutrient components).

The finding of wide habitat differences between communities classified to the same alliance. and by some authors treated as one association. shows how little known are the habitat requirements of aquatic vegetation communities. It is also evidence that regrettably, in many cases the descriptive data underlining the similarities of the habitats presented in some phytosociological papers are highly inexact and sometimes even incorrect. This proves the correctness and necessity of further research on water and rush vegetation habitats. Such studies should be more versatile in the future. It seems essential to take into account the respective properties of the habitats in relation to various types of communities formed by species with different biology. It would also be important to investigate the modifying influence of plant communities on the habitat in various time aspects (e.g. in the course of $24 \mathrm{~h}$, the vegetation season, many seasons). In further research corresponding ecotypes should be also taken into account in the case of some aquatic and rush plants, which could have different habitat requirements. On account of the facial development of most phytocenoses the occurrence of ecotypes may be the cause of wide ecological distinctiveness, even within one narrowly established association. Rejewski (1981) and Wiegleb (1984) called attention to these problems. 
In studies of ecological amplitudes of aquatic and rush vegetation attention should be devoted to some matters of methodical nature. Appropriate sampling of the substrate is particularly important for obtaining comparable results. The samples should be taken from the rhizome-root layer. This layer in various communities lies at various depths in dependence on the substrate type.

\section{REFERENCES}

A rendt K., 1981. Pflanzengesellschaften von Fliessgewässern als Indikatoren der Gewässerverschmutzung dargestellt am Beispiel des Uecker-und Havelsystems. Limnologica 13: 485-500.

Braun-Blanquet J., 1951. Pflanzensoziologie. Springer Verlag. Wien.

Dąmbska I., 1961. Roślinne zbiorowiska ieziorne okolic Sierakowa i Międzychodu. PTPN, Wydz. Mat.-Przyr. 23 (4): 1-120.

Felzines J. C., 1977. Analyse des relations entre la mineralisation des eaux douces stagnantes et la distribution des végétaux qui les peuplent. Ann. Sci. Nat. Bot. Paris, 12th ser. 18: 221-249.

Hartog C. den., Segal S., 1964. A new classification of the water plant communities. Acta Bot. Neerl. 13: 367-393.

Hermanowicz W., Dożańska W., Dojlido J., Koziorowski B., 1976. Fizyczno-chemiczne badanie wody i ścieków. Arkady, Warszawa.

Hilbig H., 1971. Übersicht über die Pflanzengesellschaften des südlichen Teiles der DDR. I. Die Wasserpflanzengesellschaften. Hercynia, N.F. 8: 4-33.

Jentys-Szaferowa J., 1951. Graficzna metoda porównywania kształtów roślinnych. Kosmos. Ser. A. $66: 346-377$.

Kłosowski S., Tomaszewicz H., 1984. Typhetum angustifoliae and Typhetum latifoliae as indicators of various habitats. Pol. Arch. Hydrobiol. 32: 245-255.

Kłosowski S., 1985. Habitat requirements and bioindicator value of the main communities of aquatic vegetation in north-east Poland. Pol. Arch. Hydrobiol. 32: 7-29.

Kłosowski S., (in press). Cladietum marisci (All. 1922) Zobrist 1935 w północno-wschodniej Polsce na tle warunków siedliskowych. Fragm. Flor. Geobot.

Kohler A., 1971. Zur Ökologie submerser Gefäss-Makrophyten in Fliessgewässern. Ber. Dtsch. Bot. Ges. 84: 713-720.

Kohler A., Brinkmeier R., Vollrath H., 1974. Verbreitung und Indikatorwert der submersen Makrophyten in Fliessgewässern der Friedberger. An. Ber. Bayer. Bot. Ges. 45: 5-36.

Matuszkiewicz W., 1974. Próba systematyzacji warunków środowiska glebowego w zbiorowiskach leśnych. Phytocenosis 3: 113-170.

Melzer A., 1976. Makrophytische Wasserpflanzen als Indikatoren des Gewässerzustandes oberbayerischer Seen. Diss. Bot. 34: 1-195.

Meriaux J. L., 1978. Etude analytique et comparative de la végétation aquatique d'étangs et marais du Nord de la France (Vallée de la Sensée et Bassin Houillier du Nord-Pas de Calais). Documents Phytosoc. N.S. 3: 1-244.

Misra R. D., 1938. Edaphic factors in the distribution of aquatic plants in English lakes. J. Ecol. 26: 411-451.

Moyle I. B., 1945. Some chemical factors influencing the distribution of aquatic plants in Minnesota. Amer. Middl. Nat. 34: 402-420. 
Nieckuła M., Podyma W., 1985. Habitat conditions of astatic pools and differentiation of vegetation connected with them. Acta Soc. Bot. Pol. 54: 131-145.

Oberdorfer E., 1977. Pflanzensoziologie. Süddeutsche Pflanzengesellschaften 10: 1-311.

Olsen S., 1950a. Aquatic plants and hydrospheric factors. I. Aquatic plants in SW-Jutland, Denmark. Svensk Bot. Tidskr. 44: 1-34.

Olsen S., 1950b. Aquatic plants and hydrospheric factors. II. The hydrospheric types. Svensk Bot. Tidskr. 44: 332-374.

Pearsall W. H., 1920. The aquatic vegetation of the English lakes. J. Ecol. 8: 163-201.

Peverly J. H., 1979. Elemental distribution and macrophyte growth downstream from an organic soil. Aquat. Bot. 7: 319-338.

Pietsch W., 1972. Ausgewählte Beispiele für Indikatoreigenschaften höherer Wasserpflanzen. Arch. Naturschutz. Landschaftsforsch. 12: 121-151.

Podbielkowski Z., Tomaszewicz H., 1974. Syntaxonomic position of Hydrocharitetum morsus-ranae van Langendonck 1935. Acta Soc. Bot. Pol. 43: 377-380.

Popiołek Z., 1973. Roślinność wodna i przybrzeżna jezior okolic Ostrowa Lubelskiego na tle warunków siedliskowych. Cz. III. Jezioro Miejskie. Ann. UMCS, Sec. C, 28: 191-213.

Rejewski M., 1977. Roślinność naczyniowa jeziora Jeziorak. Acta Uniw. Nicolai Copernici. Pr. Limnol. 40 (10): 59-88.

Rejewski M., 1981. Roślinność jezior rejonu Laski w Borach Tucholskich. Rozpr. Uniw. Mikołaja Kopernika. Toruń.

Seddon B., 1972. Aquatic macrophytes as limnological indicators. Freshwater Biol. 2: 107-130.

Segal S., 1968. Ein Einteilungsversuch der Wasserpflanzengesellschaften. Ber. über das Intern. Symp. in Stolzenau (Wesser 1964). Den Haag. pp. 191-211.

Tomaszewicz H., 1969. Roślinność wodna Jeziora Zegrzyńskiego. Acta Soc. Bot. Pol. 38: $401-424$.

Tomaszewicz H., 1973. The position of Scirpo-Phragmitetum W. Koch 1926 in systematics. Acta Soc. Bot. Pol. 42: 279-290.

Tomaszewicz H., 1977a. Dynamics and systematic position of Thelypteridi-Phragmitetum Kuiper 1957. Acta Soc. Bot. Pol. 46: 331-338.

Tomaszewicz H., 1977b. Proposal of new syntaxonomic classification of Myriophyllo- $\mathrm{Nu}$ pharetum W. Koch 1926 phytocenoses and their distribution in Poland. Acta Soc. Bot. Pol. 46: 423-436.

Tomaszewicz H., 1979. Roślinność wodna i szuwarowa Polski. Rozprawy UW, Wydawnictwa UW, Warszawa.

Tomaszewicz H., Kłosowski S., 1985. Roślinność wodna i szuwarowa jezior Pojezierza Sejneńskiego. Monogr. Bot. 67: 69-141.

Wheeler B. D., Giller K. E., 1982. Status of aquatic macrophytes in an undrained area of fen in the Norfolk Borads, England. Aquat. Bot. 12: 277-296.

Wherry E. T., 1922. Note on specific acidity. Ecology 3: 346-347.

Wiegleb G., 1978. Untersuchungen über den Zusammenhang zwischen hydrochemischen Umweltfaktoren und Makrophytenvegetation in stehenden Gewässern. Arch. Hydrobiol. 83: 443-484.

Wiegleb G., 1983. A phytosociological study of the macrophytic vegetation of running waters in Western Lower Saxony (Federal Republic of Germany). Aquat. Bot. 17: 251-274.

Wiegleb G., 1984. A study of habitat conditions of the macrophytic vegetation in selected river systems in Western Lower Saxony (Federal Republic of Germany). Aquat. Bot. 18: $313-352$. 
Wiegleb G., Todeskino D., 1983. Habitat conditions of Potamogeton alpinus Balbis stands and relation to its biological characteristics. Proc. Int. Symp. Aquat. Macrophytes, Nijmegen, September 1983, pp. 311-316.

\section{Wymagania siedliskowe fitocenoz Polygonetum natantis Soó 1927 i Potamoge- tonetum natantis Soó 1927 w pólnocno-wschodniej Polsce}

\section{Streszczenie}

Badano wymagania siedliskowe dwóch zbiorowisk roślinności wodnej: Polygonetum natantis Soó 1927 i Potamogetonetum natantis Soó 1927 w północno-wschodniej Polsce. Na podstawie porównania właściwości fizycznych i chemicznych wody i podłoża z 29 fitocenoz Polygonetum natantis i 33 fitocenoz Potamogetonetum natantis stwierdzono, że badane zbiorowiska związane są z odmiennymi typami siedlisk i mają różną wartość wskaźnikową. Fitocenozy Polygonetum natantis związane są głównie $\mathrm{z}$ podłożami mineralnymi, ubogimi $\mathrm{w}$ składniki pokarmowe i siedliskami wodnymi stosunkowo żyznymi ale o szerokich amplitudach właściwości fizycznych $\mathrm{i}$ chemicznych. Natomiast fitocenozy Potamogetonetum natantis są związane $\mathrm{z}$ wodami ubogimi w składniki biofilne i podłożami stosunkowo żyznymi, wykazującymi szerokie zakresy wartości większości składników mineralnych i czynników siedliska. Przeprowadzone badania wykazały, że zarówno Polygonetum natantis, jak i Potamogetonetum natantis przedstawiają wyraźnie określone pod względem fitosocjologicznym i ekologicznym jednostki o randze zespołu. Stanowi to bezpośrednie potwierdzenie słuszności wąskiego, opartego na domiacji florystycznej klasyfikowania zbiorowisk roślinności wodnej. 